PRINTED IN

GREAT BRITAIN B HEADLEY BROTHERS LTD

IO9 KINGSWAY LONDON WC2B 6PX

AND ASBFORD TENT

https://doi.org/10.1192/S0007125000000490 Published online by Cambridge University Press 


\section{The Presidential Election and the Future}

The postal vote among Fellows and Members of the Royal College of Psychiatrists resulted in the election to the Presidency of Professor Martin Roth. This was on the first vote, by a large and decisive margin.

Professor Roth was appointed in 1956 to the Chair of Psychological Medicine at the University of Durham, later the University of Newcastle upon Tyne, and is Head of the Departments of Psychological Medicine at the Royal Victoria Infirmary and the Newcastle General Hospital. In these capacities he has shown himself an inspiring teacher and leader of research, and an energetic and helpful colleague with other professors and departmental heads in University affairs. His long period of service on the Medical Research Council and Clinical Research Board, his work for W.H.O., and his wide international repute and relationships should prove of value in forging some of the links at home and abroad that the Royal College will need to make its influence felt, particularly in the early years.

The election of our first President is the result of a democratic process which was built into the structure of the College from its earliest planning. The pioneers who, at such labour, built these foundations foresaw that healthy development of the College and the united loyalty of all those who had chosen psychiatry for their vocation could only be assured if all who were qualified could be directly involved in the key process of government: the choice of the governors. Holders of all offices and seats on the Council are chosen by postal ballot, i.e. by the general membership, unhindered by the need of attending any meeting and therefore independently at any time, now or in the future, of the wishes or predilections of any ruling 'establishment'.

The debt that the College owes to these founding fathers, who laboured so long to realize our aims and who planned so wisely, is one which will never be forgotten and can never be repaid.
It would be appropriate to pay special tribute here to those among them who were deservedly nominated in the Presidential election. No tribute could have been too great for the immense exertions of Dr. A. B. Monro on whom, as General Secretary of the Royal MedicoPsychological Association, the main burden fell, supported as he was by a succession of Presidents and a hard-working committee, including Dr. J. G. Howells as one of its most energetic members. An equally valuable contribution has been made by the Association's Registrar, Dr. William Sargant, who built up the strength of the Association by providing for the younger generations of psychiatrists teaching courses in which they received the inspiration of learning the best and most modern methods of treatment, whether physical, psychological or social The Maudsley Bequest lectures stirred interest and enthusiasm and were widely appreciated.

These are formative years for the new College. We shall not be expected to follow, with slavish imitation, patterns set by Colleges with centuries of illustrious history behind them. How we achieve our aims is indeed governed by prescribed rules, by our Charter and Bye-laws. But the aims are for us to decide. After centuries of neglect, psychiatry has become a sister service with medicine and surgery. The rôle of a Cinderella is no longer appropriate to the maturity she has reached, to her powers and her duties. To the community, psychiatry owes not only help for those who are mentally ill but, more generally, an informed contribution to the relief of human suffering more widely envisaged. And to her own disciples she owes not only positions of responsibility and esteem but encouragement and opportunity for some of the most gifted and idealistic of the younger generation, with whom the future of the Royal College mainly lies. These are the often very talented young men and women, who seek in psychiatry an avenue for an attack on age-old ills and sicknesses which we are at last beginning 
to recognize. They are aware, more acutely than an older generation, of what psychiatry offers in approaching such contemporary problems as alcoholism, drug dependence, delinquency and violence, as well as neuroses and psychoses; and they are attracted by the skills to be mastered and the opportunities for service that offer themselves.

The raising of professional standards and the improvement of facilities for postgraduate education will inevitably be first among the College's priorities. But the activities of its various Sub-Committees foreshadow other important rôles that can now be developed with fresh vigour and enthusiasm. The Research and Clinical Section of the old Association has, through its work, already set a pattern for fruitful scientific collaboration between psychi- atrists in different centres. The emergence of the Royal College will add a powerful impetus to such endeavours. Having regard to the range of disciplines and skills that its membership spans, the College should be able to express itself on certain issues of public importance with that blend of objective and critical judgement and good sense that the practice of clinical psychiatry by means of scientific outlook and learning can, at its best, confer. And its new status as a Royal College should help to ensure that in matters in which a psychiatric viewpoint is relevant its counsels are heeded. It is a time of exciting new opportunities and difficult challenges, and a spirit of co-operation within the College should ensure that the many portents of success as we commence are translated into reality. 